\title{
Higher anticholinergic burden from medications is associated with significant increase in markers of inflammation in the EPIC-Norfolk prospective population-based cohort study
}

\author{
RIA SANGHAVI ${ }^{1}$, Tiberiu Pana ${ }^{2}$, Hulkar Mamayusuppova ${ }^{2}$, Ian Maidment ${ }^{3}$, Chris Fox ${ }^{4}$, \\ S.Matthijs Boekholdt ${ }^{5}$, Mamas Mamas ${ }^{6}$, Nicholas Wareham ${ }^{7}$, Kay-tee Khaw ${ }^{8}$, and Phyo \\ Myint $^{2}$ \\ ${ }^{1}$ University of Central Lancashire \\ ${ }^{2}$ University of Aberdeen \\ ${ }^{3}$ Aston University \\ ${ }^{4}$ Medical School \\ ${ }^{5}$ University of Amsterdam \\ ${ }^{6}$ Keel Cardiovascular group \\ ${ }^{7} \mathrm{MRC}$ Epidemiology Unit \\ ${ }^{8}$ University of Cambridge
}

June 3, 2021

\begin{abstract}
Background: Higher anticholinergic burden from medications is associated with increased risk of cardiovascular disease and cognitive function decline. A mechanistic pathway has never been established. We aimed to determine whether chronic inflammation may mediate these associations. Methods: Participants were drawn from the European Prospective Investigation into Cancer, Norfolk cohort (40-79 years at baseline). The anticholinergic cognitive burden score (ACB) was calculated at baseline/first (1HC) (1993/97) and second (2HC) (1998/2000) health checks. Plasma fibrinogen and C-reactive protein (CRP) were measured during $1 \mathrm{HC}$ and Tumour Necrosis Factor alpha (TNF- $\alpha$ ) and interleukin 6 (IL-6) during 2HC. Cross-sectional associations between ACB and inflammatory markers were examined for $1 \mathrm{HC}$ and $2 \mathrm{HC}$, respectively. The prospective association was also examined between $1 \mathrm{HC} \mathrm{ACB}$ and $2 \mathrm{HC}$ inflammatory markers. All models adjusted for age, sex, lifestyle factors, comorbidities and medications. Results: 17,678 and 22,051 participants were included in cross-sectional analyses for CRP, and fibrinogen, respectively. A total of 5,101 participants with available data for TNF- $\alpha$ and IL-6 were included in the longitudinal analyses. Cross-sectionally, a point increase in the ACB was associated with a significant increase in all inflammatory markers (beta (standard error): fibrinogen - 0.035g/l (0.006), p<0.001; CRP 0.284mg/l (0.044), p<0.001; TNF- $\alpha$ 0.031pg/ml (0.010), $\mathrm{p}=0.002$; and IL-6 $0.112 \mathrm{pg} / \mathrm{ml}(0.033), \mathrm{p}=0.001$. Longitudinally, a unit increase in the ACB was associated with a significant increase in TNF- $\alpha 0.028 \mathrm{pg} / \mathrm{ml}(0.011), \mathrm{p}=0.013$ and IL-6 $0.076 \mathrm{pg} / \mathrm{ml}(0.035), \mathrm{p}=0.029$. Conclusion: Higher anticholinergic burden was significantly associated with higher inflammatory markers. Inflammation may mediate the relationship between exposure to anticholinergic medications and adverse outcomes
\end{abstract}

\section{INTRODUCTION}

Anticholinergic medications block the effect of the neurotransmitter acetylcholine by inhibiting muscarinic receptors [1] and are increasingly being prescribed to older people for common conditions including asthma, urinary incontinence and dementia [2]. Anticholinergic effects are present in drugs that are extensively used, such as antiemetics, antihistamines, antihypertensives and tricyclic antidepressants [3]. If one or more of 
such medications are taken, they can cause excessive anticholinergic effects due to their cumulative effects, a phenomenon also known as anticholinergic burden [4].

Older people are at a particularly higher risk of anticholinergic complications due to (a) increased risk of polypharmacy including medications with anticholinergic properties, (b) age-related reductions in central cholinergic pathways and (c) decreases renal and hepatic clearance of drugs [4]. It was suggested that $48 \%$ of the ageing population may take one or more anticholinergic medications [5]. Higher anticholinergic burden (ACB) scores are also associated with an increased risk of cardiovascular disease and mortality [6,7], dementia [8] and adverse effects in cognitive and physical function [9]. Nevertheless, potential mechanistic pathways between these associations have not been identified.

Inflammation plays an important role in the pathogenesis of cardiovascular disease $[10,11,12]$, and dementia [13]. Raised inflammatory markers have also been linked to depression [14] and functional decline in older people [15]. The Vagus nerve may mediate inflammation through 'the inflammatory reflex' [16]. Previous preclinical data suggest that central muscarinic-dependent vagal activation contributes to the downregulation of inflammatory responses [17].

Therefore, we hypothesised that increased anticholinergic burden leads to increased inflammation by blocking central muscarinic-dependent vagal activation. This may mediate the previously described relationships between anticholinergic burden and adverse outcomes. No previous investigations have assessed the relationship between antimuscarinic activity and inflammation in a population sample. In this study, we aimed to examine the cross-sectional and prospective relationships between anticholinergic burden from medications and important inflammatory markers (plasma fibrinogen, CRP, TNF- $\alpha$ and IL-6) in a large UK population-based study.

\section{METHODS}

\section{Participants}

The participants were drawn from 25,639 men and women who enrolled in the EPIC-Norfolk study at baseline (first health check) between 1993 and 1998. The study protocol has been previously described [18]. Study participants were followed up between 1998 and 2000 and 15,786 participants attended the second health check (2HC). The Norwich Research Ethics Committee approved the study. Figure 1 summarises the timeline of the EPIC-Norfolk study and the analyses undertaken.

\section{Measurements}

During both health checks, trained nurses measured weight, height, and body mass index (BMI) using standardized procedures. Participants also completed a health and lifestyle questionnaire that collected information on physical activity, smoking status, alcohol consumption, co-morbid conditions and medications. The Food Frequency Questionnaire (FFQ) was used to measure participants' habitual dietary pattern during the previous year. Non-fasting venous blood samples were also taken. From each individual, $\sim 40 \mathrm{mls}$ of blood was drawn and serum, plasma, erythrocytes and buffy coat were aliquoted in plastic straws of $0.5 \mathrm{ml}$ each. These straws were then heat-sealed and stored under liquid nitrogen $\left(-196^{\circ} \mathrm{C}\right)$ in a centralized biobank.

\section{Exposure}

Medications with anticholinergic properties were identified by searching the database for exact and similar entries for both generic and brand name drugs. A corresponding anticholinergic class/score was allocated to each medication: class 0 (none), class 1 (probable, score 1), classes 2 and 3 (definite, score 2 and 3, respectively). This was based on the criteria of the Anticholinergic Cognitive Burden (ACB) scale developed by Boustani et al. [19] since this is one of the most well-known scales and validated against many clinical outcomes of interest. Subsequently, the total anticholinergic burden was then calculated for each participant by adding the individual ACB scores of all their medications at baseline. Participants were divided into six groups according to their total ACB score at baseline: 0, 1, 2, 3, 4, [?]5 (due to small sample size for ACB score 6 and above) for meaningful analysis. 


\section{Outcome Measures}

The inflammatory markers were the outcomes of interest: plasma fibrinogen, CRP, IL- 6 and TNF- $\alpha$. Fibrinogen $(\mathrm{g} / \mathrm{L})$ and CRP $(\mathrm{mg} / \mathrm{L})$ were available for a sub-sample of $1 \mathrm{HC}$ and IL-6 (pg/mL) and TNF- $\alpha(\mathrm{pg} / \mathrm{mL})$ were available for a sub-sample in the $2 \mathrm{HC}$. Non-fasting venous blood samples and $30 \mathrm{ml}$ of blood was drawn from each individual. Serum, plasma, erythrocytes and buffy coat were aliquoted in plastic straws of $0.5 \mathrm{ml}$ each. These straws were then heat-sealed and stored under liquid nitrogen $\left(-196^{\circ} \mathrm{C}\right)$ in a centralized biobank.

\section{Statistical Analysis}

Data were analysed using SPSS version 24.0 (SPSS Inc., Chicago, IL, USA). Descriptive statistics were presented for the overall sample and by ACB score groups. Differences between ACB groups were assessed using the Pearson's chi-squared test for categorical variables and analysis of variance (ANOVA) for normally distributed continuous variables or Kruskal-Wallis test for continuous variables that were not normally distributed.

Linear regression analysis was performed to determine the cross-sectional relationship of baseline/1HC ACB and $1 \mathrm{HC}$ inflammatory markers, fibrinogen and CRP. Linear regression was also performed to determine the cross-sectional association of $2 \mathrm{HC}$ ACB and $2 \mathrm{HC}$ inflammatory markers IL-6 and TNF- $\alpha$. Longitudinal relationship between baseline/1HC ACB data and 2HC inflammatory markers IL-6 and TNF- $\alpha$, was also carried out.

Four statistical models were constructed to assess the effects of potential confounding factors in a group sequential fashion. Model A was unadjusted, model B was adjusted for age and sex, model C was adjusted for age, sex and lifestyle factors (BMI, alcohol consumption, smoking status, total fruits and vegetables consumed and physical activity) and lastly, model D, the fully adjusted model was adjusted for the variables: age, sex, lifestyle factors, co-morbidities (diabetes, stroke, cancer and heart attack), medications (lipid lowering drugs, non-steroidal anti-inflammatory drugs (NSAIDs)) and total cholesterol.

\section{RESULTS}

There were 25,639 participants that attended the 1HC. A total of 3,588 participants were excluded from the fibrinogen analysis and 7,961 individuals were excluded from the CRP analysis. Therefore, a total of 22,051 and 17,678 participants were included in the fibrinogen and CRP analyses respectively. In the $2 \mathrm{HC}$, out of the 15,786 participants who attended, only 5,101 men and women were included in the analysis for TNF- $\alpha$ and IL-6 after the exclusion of 10,685 participants with missing data for these variables. Figure 2 displays the participant population flowchart. All exclusions were made due to missing data. Online Resources 1 and 2 present the participants missing data from each variable in the first and second health check, respectively.

\section{Descriptive Statistics}

Tables 1 and 2 detail the sample characteristics at baseline/1HC by ACB group. Table 1 details the descriptive characteristics of included participants in the fibrinogen analysis. The mean (SD) age was 59.1 years (9.3) with $54 \%$ being female. The mean (SD) plasma fibrinogen was $2.9 \mathrm{~g} / 1$ (1.0). Table 2 details the descriptive statistics of included participants in the CRP analysis. The mean age (SD) was 59.1 years (9.1) for Table 2 with $55.1 \%$ being female. The median (IQR) CRP was $1.5 \mathrm{mg} / 1$ (0.7-3.3).

There were significant differences between ACB groups for all variables considered except fruit and vegetable consumption. People in the higher ACB groups were older, had higher BMI, total cholesterol level and a lower level of physical activity. NSAIDs and lipid lowering drug usage was more prevalent in higher ACB groups. In terms of co-morbidities, high ACB score was associated with a greater percentage of individuals with a prior history of stroke, cancer, diabetes and myocardial infarction. Significantly, higher mean fibrinogen and median CRP were observed in higher $\mathrm{ACB}$ groups compared to $\mathrm{ACB}=0$ group.

Table 3 details the characteristics of participants in the $2 \mathrm{HC}$ by the ACB groups. There were 5,101 participants of which $61.5 \%$ were women and the mean (SD) age was 63.1 years (8.9). The mean (SD) TNF- $\alpha$ was $2.0 \mathrm{pg} / \mathrm{ml}(0.8)$ whilst the median (IQR) IL-6 was $0.6(0.5-0.9)$. People in the higher ACB groups were 
older, had higher BMI and were less likely to be active. There were no significant sex differences between ACB groups or in terms of fruit and vegetable consumption. There were higher proportions of NSAIDs and lipid lowering drugs usage in higher ACB groups. With regards to self-reported illnesses, high ACB was associated with a greater percentage of individuals with a prior history of stroke, diabetes and myocardial infarction. However, there was no significant difference between ACB groups in terms of cancer prevalence. There was a significant difference between ACB groups in terms of both TNF- $\alpha$ and IL-6. The levels of these inflammatory markers were higher in participants in higher $\mathrm{ACB}$ groups compared to $\mathrm{ACB}=0$ group.

\section{Cross-sectional analyses}

Table 4 shows the results of linear regression analysis for the cross-sectional relationship between baseline ACB groups and inflammatory markers. All the adjusted models showed that a unit increase in the ACB score was associated with a significant increase in all the inflammatory markers. After complete multivariable adjustment (model 4), a unit increase in ACB score was associated with an increase of fibrinogen of $0.035 \mathrm{~g} / \mathrm{l}$ $\{(0.006) p<0.001\}$, CRP of $0.284 \mathrm{mg} / 1\{(0.044) p<0.001\}$ (in $1 \mathrm{HC})$, TNF- $\alpha$ of $0.031 \mathrm{pg} / \mathrm{ml}\{(0.010) p=0.002\}$ and IL-6 of $0.112 \mathrm{pg} / \mathrm{ml}\{(0.033) p=0.001\}$ (in $2 \mathrm{HC}$ ), respectively.

\section{Longitudinal analysis}

Table 5 shows the results of the longitudinal analyses for prospective relationship between 1HC ACB and inflammatory markers measured at the $2 \mathrm{HC}$. All models revealed a statistically significant association between $\mathrm{ACB}$ score at $1 \mathrm{HC}$ and increase in the circulating levels of inflammatory markers measured at $2 \mathrm{HC}$. Upon full multivariable adjustment, a unit increase in the ACB score was associated with a significant increase in TNF- $\alpha$ and IL-6 of $0.028 \mathrm{pg} / \mathrm{ml}\{(0.011) p=0.013\}$ and $0.076 \mathrm{pg} / \mathrm{ml}\{(0.035) p=0.029\}$, respectively.

\section{DISCUSSION}

We describe for the first time the association between anticholinergic burden and inflammation at a population level. Cross-sectionally, increases in ACB scores were independently associated with significant increases in fibrinogen, CRP, TNF- $\alpha$ and IL-6. Longitudinally, increases in ACB scores were independently associated with increases in TNF- $\alpha$ and IL-6. To the best of our knowledge, this is the first report which provides possible mechanistic link through inflammatory pathways between anticholinergic medications and adverse longer term outcomes at a population level.

Increases in such inflammatory markers in long term can lead to adverse outcomes. The meta-analysis by Kaptoge et al. [20] found a significant 17\% increase (RR- 1.17 (1.09-1.25)) and 25\% increase (RR- 1.25 (1.19-1.32) ) in incident CHD/non-fatal MI associated with a 1-SD increase in TNF- $\alpha$ and IL-6 respectively. Our study suggests that 1- and 3-point ACB increases would translate into $0.646 \%$ and $\sim 2 \%$ relative risk increases in TNF- $\alpha$ - mediated incident CHD/non-fatal MI respectively [20]. Furthermore, our findings also suggest that 1- and 3-point ACB increases would translate into $1.13 \%$ and $3.39 \%$ relative risk increases in IL6-mediated incident CHD/non-fatal MI, respectively [20]. Longitudinally, a 1-point increase in ACB would translate into a $0.595 \%$ and $0.75 \%$ increase in the relative risk of TNF- $\alpha$-mediated incident $\mathrm{CHD} /$ non-fatal MI and IL-6-mediated incident CHD/non-fatal MI respectively [20].

The meta-analysis by Yano et al. [21] established that a 1-SD increase in fibrinogen was associated with a $30 \%$ increase (RR- 1.3 (1.2-1.4)) in all-cause mortality, a 20\% increase (RR- 1.2 (1.1-1.4)) in cardiovascular disease and a 30\% increase (RR-1.3 (1.2 to 1.5)) in cancer. Cross-sectionally, our study found a 1-point increase in $\mathrm{ACB}$ would translate into a $1.05 \%$ increase in the relative risk of all-cause mortality, a $0.7 \%$ increase in the relative risk of cardiovascular disease and a 1.05\% increase in the relative risk of cancer [21]. In addition, Emerging Risk Factors Collaboration [22] also defined an increase in relative risk of CHD and ischaemic stroke associated with CRP. Our findings revealed that an increase in ACB would translate into an increase in the relative risk of CHD and ischaemic stroke.

The results of our study alongside previous investigations linking markers of chronic inflammation with a variety of adverse incident outcomes allow for the first time to quantify the contribution of inflammation in mediating the relationship between ACB and adverse outcomes. The 'inflammatory reflex' may mediate 
the described relationships between anticholinergic burden and adverse outcomes. We hypothesised that an increased anticholinergic burden may lead to raised inflammatory markers due to the 'inflammatory reflex' [16]. This mechanism also known as the cholinergic anti-inflammatory pathway suggests that the Vagus nerve, a part of the parasympathetic nervous system, has an anti-inflammatory role. Central vagus nerve stimulation downregulates inflammatory responses and thus we hypothesised that increased anticholinergic burden leads to increased inflammation by blocking central muscarinic-dependent vagal activation [17].

Based on literature, our findings can be extrapolated that a 3-point increase in ACB-related chronic inflammation can be linked to an increase in relative risk of up to $\sim \%$ in cancer, cardiovascular disease and mortality. Furthermore, a previous study [7] including participants from the EPIC-Norfolk cohort found that people with a total ACB [?]3 from medications had a relative risk increase of mortality by $83 \%$ (HR- 1.83 (1.53-2.20) ) and a $117 \%$ increase in incident CVD. The increased risk of up to $3.39 \%$ in incident CHD/nonfatal MI after a 3-point increase in ACB inferred from the study by Kaptoge et al. [20] would account for only $2.9 \%$ of the entire $\mathrm{ACB}[?] 3$-associated excess risk of incident CVD.

Indeed, there may be other plausible mechanisms other than chronic inflammation that may mediate the association between ACB from medications and adverse outcomes. Anticholinergic drugs have been found to suppress the parasympathetic control of heart rate, which is linked to an increased incidence of myocardial ischemia and tachyarrythmias that are known to increase the risk of embolic strokes and sudden cardiac death [23]. Anticholinergic medications can also lead to ischaemia due to their pro-ischaemic properties [24]. In addition, the arterial baroreflex is an important mechanism that protects against strokes [25]. The anticholinergic medications disrupt vagal nerve activity which is involved in the activation of arterial baroreflex therefore reducing its protective effects [25].

Our study has several strengths. The study benefited form using data from a large, prospective populationbased study. We were able to delineate both the cross-sectional and longitudinal associations between ACB and markers of inflammation. The data were also prospectively collected, minimising recall bias. Additionally, a well-validated ACB score was used, and we were able to control for a variety of sociodemographic and lifestyle factors, comorbidities and relevant medications.

We acknowledge some limitations. As a volunteer study with long-term follow-up, a degree of healthy volunteer bias is possible. However, the baseline characteristics of the EPIC-Norfolk participants are similar to other UK representative population samples [18]. The participants in this study were almost completely (>99\%) White British, however, it is unlikely biological mechanisms will be hugely different from other ethnicities. Potential confounders adjusted were measured at baseline, and it is possible that these may vary during the follow-up period. Although we were able to calculate the total ACB score, we were not able to identify particular drugs and the dosages that are associated to adverse outcomes. In addition, as the ACB score was calculated at baseline, we were unable to account for any changes in ACB score during the follow-up period for longitudinal analysis. Nevertheless, it is likely that individuals would either maintain similar anticholinergic exposure or be exposed to increasing anticholinergic burden during follow-up because the use of medications with anticholinergic properties would increase as participants age and accrue more disease burden and increasing polypharmacy. However, both cross-sectional and longitudinal analyses results for TNF- $\alpha$ and IL-6 were consistent.

This study along with future robust experimental studies may change the anticholinergic burden paradigm, by recognizing the chronic inflammatory state associated with anticholinergic medications as a therapeutic target in the era of targeted immune therapy for cardiovascular prevention. The landmark CANTOS trial used canakinumab to target the interleukin- $1 \beta$ innate immunity pathway, leading to a significantly lower incidence of recurrent cardiovascular events [26]. Furthermore, colchicine has been shown to be effective at preventing major adverse cardiac events after a myocardial infarction [27] and preventing cardiovascular events in patients with recent myocardial infarction [28] and stable coronary disease [29,30]. Future studies should also explore whether systematic attempts to reduce the anticholinergic burden reduces inflammation and consequently, the risk of such adverse outcomes. 
In conclusion, using data from a large-scale prospective cohort study from UK, we determined the crosssectional and longitudinal associations between the anticholinergic burden and inflammatory markers. Higher anticholinergic burden is significantly associated with higher inflammatory markers both cross-sectionally and longitudinally after multivariable adjustment. Furthermore, we underlined how chronic inflammation may be a previously unrecognized potential mechanism for the observed association between anticholinergic burden and adverse outcomes.

\section{DECLARATIONS}

\section{Acknowledgements:}

We are grateful to all the participants who have been part of the project and to the many members of the study teams at the University of Cambridge who have enabled this research. We would also like to acknowledge the principal investigators and staff of the EPIC-Norfolk study.

\section{Funding}

The EPIC-Norfolk study (DOI 10.22025/2019.10.105.00004) was funded by the Medical Research Council, Grant number (MR/N003284/1 and MC-UU_12015/1) and Cancer Research UK, Grant number (C864/A14136).

\section{Conflict of Interest}

The authors have no conflicts of interest to declare that are relevant to the content of this article.

\section{Ethics Approval}

Norwich Ethics Committee approved the study in view of the retrospective nature of the study.

\section{Data Availability}

Data available on request to EPIC-Norfolk Steering Committee for their approval.

\section{Consent to participate and publish}

Informed consent was obtained from all individual participants included in the study.

\section{Authors' contributions}

Ria Sanghavi, Tiberiu A Pana and Phyo K Myint conceived the study. Ria Sanghavi performed literature search, data analysis and writing the first draft of the paper. Ria Sanghavi, Tiberiu A Pana and Phyo K Myint verified data. Nicholas J Wareham and Kay-Tee Khaw are PIs of EPIC-Norfolk Cohort. All authors commented on previous versions of the manuscript and approved the final manuscript. Phyo K Myint is the guarantor.

\section{REFERENCES}

1. Gray SL, Anderson ML, Dublin S, Hanlon JT, Hubbard R, Walker R, Yu O, Crane PK, Larson EB. Cumulative use of strong anticholinergics and incident dementia: a prospective cohort study. JAMA Internal Medicine . 2015;175(3):401-7. https://doi:10.1001/jamainternmed.2014.7663

2. Campbell N, Boustani M, Limbil T, Ott C, Fox C, Maidment I, Schubert CC, Munger S, Fick D, Miller D, Gulati R. The cognitive impact of anticholinergics: a clinical review. Clin Interventions in Aging . 2009;4:225. https://doi: 10.2147/cia.s5358

3. Ancelin ML, Artero S, Portet F, Dupuy AM, Touchon J, Ritchie K. Non-degenerative mild cognitive impairment in elderly people and use of anticholinergic drugs: longitudinal cohort study. $B m j$. 2006;332(7539):455-9. https://doi.org/10.1136/bmj.38740.439664.DE 
4. Fox C, Livingston G, Maidment ID, Coulton S, Smithard DG, Boustani M, Katona C. The impact of anticholinergic burden in Alzheimer's dementia-the LASER-AD study. Age and Ageing . 2011 Nov 1;40(6):730-5. https://doi.org/10.1093/ageing/afr102

5. Fox C, Richardson K, Maidment ID, Savva GM, Matthews FE, Smithard D, Coulton S, Katona C, Boustani MA, Brayne C. Anticholinergic medication use and cognitive impairment in the older population: the medical research council cognitive function and ageing study. Journal of the American Geriatrics Society . 2011;59(8):1477-83. https://doi.org/10.1111/j.1532-5415.2011.03491.x

6. Gamble DT, Clark AB, Luben RN, Wareham NJ, Khaw KT, Myint PK. Baseline anticholinergic burden from medications predicts incident fatal and non-fatal stroke in the EPIC-Norfolk general population.International Journal of Epidemiology . 2018;47(2):625-33. https://doi.org/10.1093/ije/dyx265

7. Myint PK, Fox C, Kwok CS, Luben RN, Wareham NJ, Khaw KT. Total anticholinergic burden and risk of mortality and cardiovascular disease over 10 years in 21,636 middle-aged and older men and women of EPIC-Norfolk prospective population study. Age and Ageing . 2015;44(2):219-25. https://doi.org/10.1093/ageing/afu185

8. Richardson K, Fox C, Maidment I, Steel N, Loke YK, Arthur A, Myint PK, Grossi CM, Mattishent K, Bennett K, Campbell NL. Anticholinergic drugs and risk of dementia: case-control study. Bmj . 2018 Apr 25;361. https://doi.org/10.1136/bmj.k1315

9.. Fox C, Smith T, Maidment I, Chan WY, Bua N, Myint PK, Boustani M, Kwok CS, Glover M, Koopmans I, Campbell N. Effect of medications with anti-cholinergic properties on cognitive function, delirium, physical function and mortality: a systematic review. Age and Ageing . 2014;43(5):604-15. https://doi.org/10.1093/ageing/afu096

10. Kritchevsky SB, Cesari M, Pahor M. Inflammatory markers and cardiovascular health in older adults. Cardiovascular Research . 2005;66(2):265-75. https://doi.org/10.1016/j.cardiores.2004.12.026

11. Kardys I, Knetsch AM, Bleumink GS, Deckers JW, Hofman A, Stricker BH, Witteman JC. C-reactive protein and risk of heart failure. The Rotterdam Study. American Heart Journal . 2006;152(3):514-20. https://doi.org/10.1016/j.ahj.2006.02.023

12. Libby P, Ridker PM, Maseri A. Inflammation and atherosclerosis.Circulation. 2002;105(9):1135-43. https://doi.org/10.1161/hc0902.104353

13. Schmidt R, Schmidt H, Curb JD, Masaki K, White LR, Launer LJ. Early inflammation and dementia: a 25-year follow-up of the Honolulu-Asia Aging Study. Annals of Neurology . 2002 Aug;52(2):168-74. https://doi.org/10.1002/ana.10265

14. Hodge DR, Hurt EM, Farrar WL. The role of IL-6 and STAT3 in inflammation and cancer. European Journal of Cancer . 2005;41(16):2502-12. https://doi.org/10.1016/j.ejca.2005.08.016

15. Verghese J, Holtzer R, Oh-Park M, Derby CA, Lipton RB, Wang C. Inflammatory markers and gait speed decline in older adults. Journals of Gerontology Series A: Biomedical Sciences and Medical Sciences. 2011;66(10):1083-9. https://doi.org/10.1093/gerona/glr099

16. Tracey KJ. The inflammatory reflex. Nature. 2002 Dec;420(6917):853-9. https://doi:10.1038/nature01321

17. Pavlov VA, Wang H, Czura CJ, Friedman SG, Tracey KJ. The cholinergic anti-inflammatory pathway: a missing link in neuroimmunomodulation. Molecular Medicine . 2003;9(5):125-34.

18. Day N, Oakes S, Luben R, et al. EPIC-Norfolk: study design and characteristics of the cohort. European prospective investigation of cancer. Br J Cancer . 1999;80:95-103.

19. Boustani M, Campbell N, Munger S, Maidment I, Fox C. Impact of anticholinergics on the aging brain: a review and practical application. Aging Health . 2008;4:311-320. https://doi.org/10.2217/1745509X.4.3.311 
20. Kaptoge S, Seshasai SR, Gao P, Freitag DF, Butterworth AS, Borglykke A, Di Angelantonio E, Gudnason V, Rumley A, Lowe GD, Jørgensen T. Inflammatory cytokines and risk of coronary heart disease: new prospective study and updated meta-analysis. European heart journal . 2014 Mar 1;35(9):578-89. https://doi.org/10.1093/eurheartj/eht367

21. Yano K, Grove JS, Chen R, Rodriguez BL, Curb JD, Tracy RP. Plasma fibrinogen as a predictor of total and cause-specific mortality in elderly Japanese-American men. Arteriosclerosis, thrombosis, and vascular biology . 2001 Jun;21(6):1065-70. https://doi.org/10.1161/01.ATV.21.6.1065

22. Gallacher JE. C-reactive protein concentration and risk of coronary heart disease, stroke, and mortality: an individual participant meta-analysis. The Lancet . 2010;375(9709):132-40. https://doi.org/10.1016/S01406736(09)61717-7

23. Singh S, Loke YK, Enright P, Furberg CD. Pro-arrhythmic and pro-ischaemic effects of inhaled anticholinergic medications. Thorax . 2013 Jan 1;68(1):114-6. http://dx.doi.org/10.1136/thoraxjnl-2011-201275

24. Eveson DJ, Robinson TG, Shah NS, Panerai RB, Paul SK, Potter JF. Abnormalities in cardiac baroreceptor sensitivity in acute ischaemic stroke patients are related to aortic stiffness. Clinical Science . 2005 May 1;108(5):441-7. https://doi.org/10.1042/CS20040264

25. Liu AJ, Zang P, Guo JM, Wang W, Dong WZ, Guo W, Xiong ZG, Wang WZ, Su DF. Involvement of Acetylcholine- $\alpha 7 \mathrm{n}$ AChR in the protective effects of arterial baroreflex against ischemic stroke. CNS neuroscience \& therapeutics . 2012 Nov;18(11):918-26. https://doi.org/10.1111/cns.12011

26. Ridker PM, Everett BM, Thuren T, MacFadyen JG, Chang WH, Ballantyne C, Fonseca F, Nicolau J, Koenig W, Anker SD, Kastelein JJ. Antiinflammatory therapy with canakinumab for atherosclerotic disease.New England journal of medicine . 2017 Sep 21;377(12):1119-31. https://doi: 10.1056/NEJMoa1707914

27. Bouabdallaoui N, Tardif JC, Waters DD, Pinto FJ, Maggioni AP, Diaz R, Berry C, Koenig W, LopezSendon J, Gamra H, Kiwan GS. Time-to-treatment initiation of colchicine and cardiovascular outcomes after myocardial infarction in the Colchicine Cardiovascular Outcomes Trial (COLCOT). European heart journal . 2020 Nov 7;41(42):4092-9. https://doi.org/10.1093/eurheartj/ehaa659

28. Hennessy T, Soh L, Bowman M, Kurup R, Schultz C, Patel S, Hillis GS. The Low Dose Colchicine after Myocardial Infarction (LoDoCo-MI) study: A pilot randomized placebo controlled trial of colchicine following acute myocardial infarction. American heart journal. 2019 Sep 1;215:62-9. https://doi:10.1016/j.ahj.2019.06.003

29. Nidorf SM, Fiolet AT, Mosterd A, Eikelboom JW, Schut A, Opstal TS, The SH, Xu XF, Ireland MA, Lenderink T, Latchem D. Colchicine in patients with chronic coronary disease. New England Journal of Medicine . 2020 Nov 5;383(19):1838-47. https://doi.10.1056/NEJMoa2021372

30. Nidorf SM, Eikelboom JW, Budgeon CA, Thompson PL. Low-dose colchicine for secondary prevention of cardiovascular disease. Journal of the American College of Cardiology . 2013 Jan 29;61(4):404-10. https://doi.org/10.1016/j.jacc.2012.10.027

\section{TABLES}

Table 1 Baseline sample characteristics for 22,051 men and women in the EPIC-Norfolk cohort (first health check) according to the total anticholinergic burden score groups.

\begin{tabular}{|c|c|c|c|c|c|c|}
\hline All & $\begin{array}{l}\text { ACB } \\
\text { score } 0 \\
\text { group }\end{array}$ & $\begin{array}{l}\text { ACB } \\
\text { score } 1 \\
\text { group }\end{array}$ & $\begin{array}{l}\text { ACB } \\
\text { score 2 } \\
\text { group }\end{array}$ & $\begin{array}{l}\text { ACB } \\
\text { score } 3 \\
\text { group }\end{array}$ & $\begin{array}{l}\text { ACB } \\
\text { score } 4 \\
\text { group }\end{array}$ & $\begin{array}{l}\text { ACB } \\
\text { score } \\
{[?] 5} \\
\text { group }\end{array}$ \\
\hline $\mathrm{n}=22$ & $\mathrm{n}=17$ & $\mathrm{n}=2252$ & $\mathrm{n}=542$ & $\mathrm{n}=677$ & $\mathrm{n}=409$ & $\mathrm{n}=562$ \\
\hline
\end{tabular}




\begin{tabular}{|c|c|c|c|c|c|c|c|c|}
\hline $\begin{array}{l}\text { Mean } \\
\text { age } \\
\text { (years) } \\
\text { (SD) }\end{array}$ & $\begin{array}{l}59.1 \\
(9.3)\end{array}$ & $\begin{array}{l}58.2 \\
(9.1)\end{array}$ & $\begin{array}{l}62.4 \\
(8.9)\end{array}$ & $\begin{array}{l}65.5 \\
(8.3)\end{array}$ & $\begin{array}{l}62.0 \\
(9.2)\end{array}$ & $\begin{array}{l}65.0 \\
(7.9)\end{array}$ & $\begin{array}{l}62.7 \\
(9.0)\end{array}$ & $<0.001$ \\
\hline $\begin{array}{l}\text { Sex } \\
(\%)\end{array}$ & & & & & & & & $<0.001$ \\
\hline Men & $\begin{array}{l}10140 \\
(46.0)\end{array}$ & $\begin{array}{l}8065 \\
(45.8)\end{array}$ & $\begin{array}{l}1059 \\
(47.0)\end{array}$ & $\begin{array}{l}294 \\
(54.2)\end{array}$ & $\begin{array}{l}274 \\
(40.5)\end{array}$ & $\begin{array}{l}214 \\
(52.3)\end{array}$ & $\begin{array}{l}234 \\
(41.6)\end{array}$ & \\
\hline Women & $\begin{array}{l}11911 \\
(54.0)\end{array}$ & $\begin{array}{l}9544 \\
(54.2)\end{array}$ & $\begin{array}{l}1193 \\
(53.0)\end{array}$ & $\begin{array}{l}248 \\
(45.8)\end{array}$ & $\begin{array}{l}403 \\
(59.5)\end{array}$ & $\begin{array}{l}195 \\
(47.7)\end{array}$ & $\begin{array}{l}328 \\
(58.4)\end{array}$ & \\
\hline $\begin{array}{l}\text { Mean } \\
\text { BMI } \\
\left(\mathrm{kg} / \mathrm{m}^{\wedge} \mathbf{2}\right) \\
(\mathrm{SD})\end{array}$ & $26.3(3.8)$ & $26.1(3.7)$ & $27.0(4.2)$ & $27.0(4.0)$ & $27.0(4.1)$ & $27.2(4.2)$ & $27.2(4.1)$ & $<0.001$ \\
\hline $\begin{array}{l}\text { Smoking } \\
\text { status } \\
(\%)\end{array}$ & & & & & & & & $<0.001$ \\
\hline Current & $\begin{array}{l}2470 \\
(11.2)\end{array}$ & $\begin{array}{l}2012 \\
(11.4)\end{array}$ & $\begin{array}{l}215 \\
(9.5)\end{array}$ & $\begin{array}{l}54 \\
(10.0)\end{array}$ & $\begin{array}{l}72 \\
(10.6)\end{array}$ & $34(8.3)$ & $\begin{array}{l}83 \\
(14.8)\end{array}$ & \\
\hline Former & $\begin{array}{l}9294 \\
(42.1)\end{array}$ & $\begin{array}{l}7186 \\
(40.8)\end{array}$ & $\begin{array}{l}1066 \\
(47.3)\end{array}$ & $\begin{array}{l}276 \\
(50.9)\end{array}$ & $\begin{array}{l}309 \\
(45.6)\end{array}$ & $\begin{array}{l}206 \\
(50.4)\end{array}$ & $\begin{array}{l}251 \\
(44.7)\end{array}$ & \\
\hline Never & $\begin{array}{l}10287 \\
(46.7)\end{array}$ & $\begin{array}{l}8411 \\
(47.8)\end{array}$ & $\begin{array}{l}971 \\
(43.1)\end{array}$ & $\begin{array}{l}212 \\
(39.1)\end{array}$ & $\begin{array}{l}296 \\
(43.7)\end{array}$ & $\begin{array}{l}169 \\
(41.3)\end{array}$ & $\begin{array}{l}228 \\
(40.6)\end{array}$ & \\
\hline $\begin{array}{l}\text { Median } \\
\text { alcohol } \\
\text { consump- } \\
\text { tion } \\
\text { (units/week } \\
\text { (IQR) }\end{array}$ & $\begin{array}{l}3.5 \\
(1.0-10.0)\end{array}$ & $\begin{array}{l}4.0 \\
(1.5-10.0)\end{array}$ & $\begin{array}{l}2.5 \\
(1.0-9.0)\end{array}$ & $\begin{array}{l}2.5 \\
(1.0-8.5)\end{array}$ & $\begin{array}{l}2.5 \\
(0.5-8.5)\end{array}$ & $\begin{array}{l}2.5 \\
(0.5-9.0)\end{array}$ & $\begin{array}{l}2.0 \\
(0.5-7.0)\end{array}$ & $<0.001$ \\
\hline $\begin{array}{l}\text { Physical } \\
\text { activ- } \\
\text { ity } \\
(\%)\end{array}$ & & & & & & & & $<0.001$ \\
\hline Inactive & $\begin{array}{l}6527 \\
(29.6)\end{array}$ & $\begin{array}{l}4745 \\
(26.9)\end{array}$ & $\begin{array}{l}857 \\
(38.1)\end{array}$ & $\begin{array}{l}251 \\
(46.3)\end{array}$ & $\begin{array}{l}248 \\
(36.6)\end{array}$ & $\begin{array}{l}188 \\
(46.0)\end{array}$ & $\begin{array}{l}238 \\
(42.3)\end{array}$ & \\
\hline $\begin{array}{l}\text { Moderately } \\
\text { inac- } \\
\text { tive }\end{array}$ & $\begin{array}{l}6351 \\
(28.8)\end{array}$ & $\begin{array}{l}5112 \\
(29.0)\end{array}$ & $\begin{array}{l}637 \\
(28.3)\end{array}$ & $\begin{array}{l}130 \\
(24.0)\end{array}$ & $\begin{array}{l}200 \\
(29.5)\end{array}$ & $\begin{array}{l}109 \\
(26.7)\end{array}$ & $\begin{array}{l}163 \\
(29.0)\end{array}$ & \\
\hline $\begin{array}{l}\text { Moderately } \\
\text { active }\end{array}$ & $\begin{array}{l}5088 \\
(23.1)\end{array}$ & $\begin{array}{l}4262 \\
(24.2)\end{array}$ & $\begin{array}{l}445 \\
(19.8)\end{array}$ & $\begin{array}{l}84 \\
(15.5)\end{array}$ & $\begin{array}{l}136 \\
(20.1)\end{array}$ & $\begin{array}{l}52 \\
(12.7)\end{array}$ & $\begin{array}{l}109 \\
(19.4)\end{array}$ & \\
\hline Active & $\begin{array}{l}4085 \\
(18.5)\end{array}$ & $\begin{array}{l}3490 \\
(19.8)\end{array}$ & $\begin{array}{l}313 \\
(13.9)\end{array}$ & $\begin{array}{l}77 \\
(14.2)\end{array}$ & $\begin{array}{l}93 \\
(13.7)\end{array}$ & $\begin{array}{l}60 \\
(14.7)\end{array}$ & $52(9.3)$ & \\
\hline $\begin{array}{l}\text { Mean } \\
\text { total } \\
\text { choles- } \\
\text { terol } \\
(\mathrm{mmol} / \mathrm{l}) \\
(\mathrm{SD})\end{array}$ & $6.2(1.2)$ & $6.1(1.1)$ & $6.3(1.2)$ & $6.4(1.3)$ & $6.3(1.2)$ & $6.4(1.3)$ & $6.4(1.3)$ & $<0.001$ \\
\hline
\end{tabular}




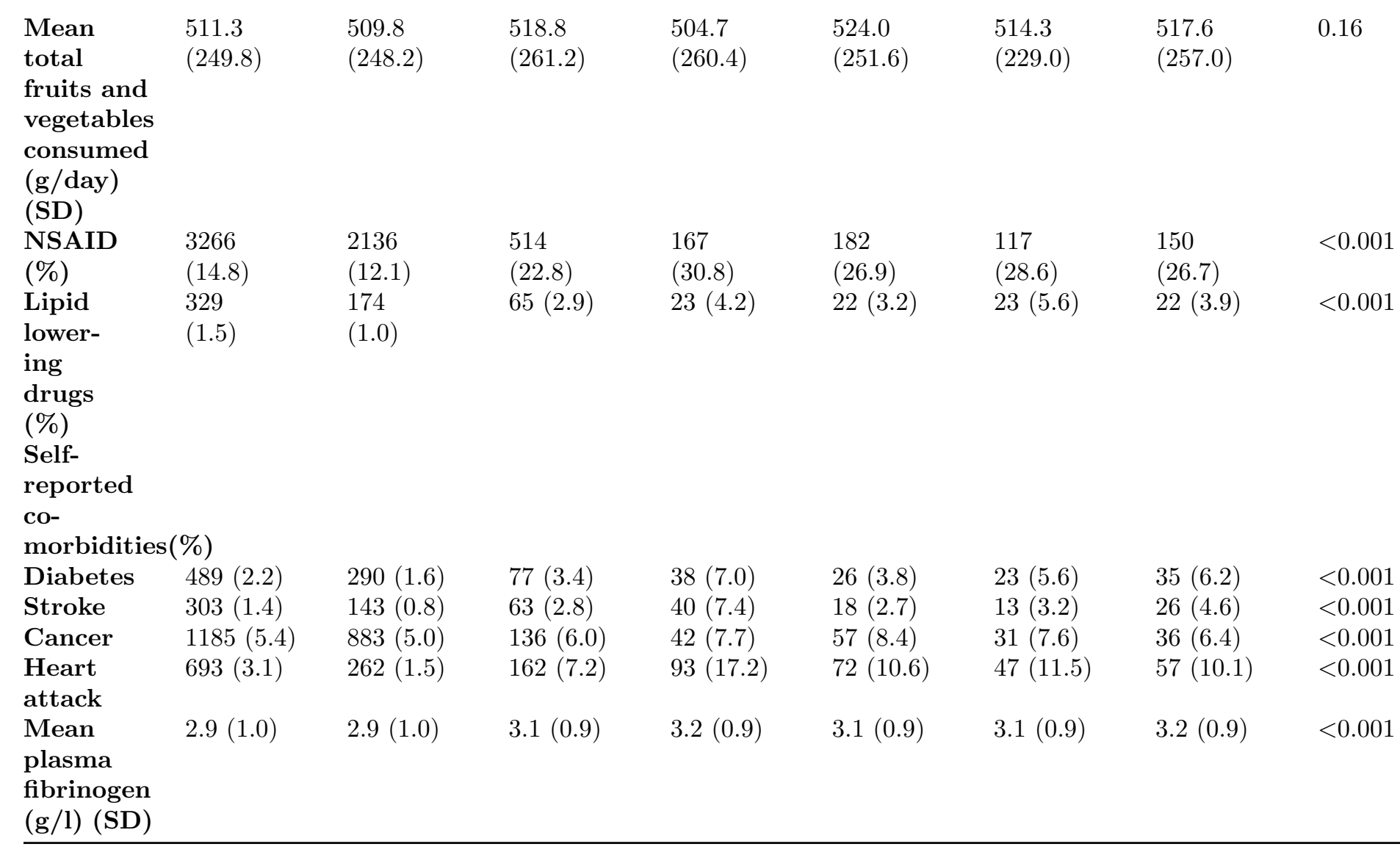

Note: Values presented are mean (SD) for normally distributed, continuous data, median (IQR) for nonnormally distributed, continuous data and number (\%) for categorical data. Total ACB was calculated with the formula of ((number of class 1 anticholinergics) + (number of class 2 anticholinergics $\times 2)+$ (number of class 3 anticholinergics $\times 3)$ ). Abbreviations: $\mathrm{ACB}$, anticholinergic cognitive burden; BMI, body mass index; NSAID, non-steroidal anti-inflammatory drugs.

Table 2 Baseline sample characteristics for 17,678 men and women in the EPIC-Norfolk cohort (first health check) according to the total anticholinergic burden score groups.

\begin{tabular}{|c|c|c|c|c|c|c|c|c|}
\hline & All & $\begin{array}{l}\text { ACB } \\
\text { score } 0 \\
\text { group }\end{array}$ & $\begin{array}{l}\text { ACB } \\
\text { score } 1 \\
\text { group }\end{array}$ & $\begin{array}{l}\text { ACB } \\
\text { score } 2 \\
\text { group }\end{array}$ & $\begin{array}{l}\text { ACB } \\
\text { score } 3 \\
\text { group }\end{array}$ & $\begin{array}{l}\text { ACB } \\
\text { score } 4 \\
\text { group }\end{array}$ & $\begin{array}{l}\text { ACB } \\
\text { score } \\
{[?] 5} \\
\text { group }\end{array}$ & $p$ valu \\
\hline & $\begin{array}{l}N= \\
17678\end{array}$ & $\mathrm{~N}=14161$ & $\mathrm{~N}=1758$ & $\mathrm{~N}=422$ & $\mathrm{~N}=560$ & $\mathrm{~N}=332$ & $\mathrm{~N}=445$ & \\
\hline $\begin{array}{l}\text { Mean } \\
\text { age } \\
\text { (years) } \\
\text { (SD) }\end{array}$ & $\begin{array}{l}59.1 \\
(9.1)\end{array}$ & $\begin{array}{l}58.2 \\
(9.0)\end{array}$ & $\begin{array}{l}62.4 \\
(8.8)\end{array}$ & $\begin{array}{l}65.4 \\
(8.2)\end{array}$ & $\begin{array}{l}62.1 \\
(9.1)\end{array}$ & $\begin{array}{l}64.8 \\
(8.2)\end{array}$ & $\begin{array}{l}62.5 \\
(9.0)\end{array}$ & $<0.001$ \\
\hline $\begin{array}{l}\text { Sex } \\
(\%)\end{array}$ & & & & & & & & $<0.001$ \\
\hline Men & $\begin{array}{l}7942 \\
(44.9)\end{array}$ & $\begin{array}{l}6343 \\
(44.8)\end{array}$ & $\begin{array}{l}805 \\
(45.8)\end{array}$ & $\begin{array}{l}232 \\
(55.0)\end{array}$ & $\begin{array}{l}226 \\
(40.4)\end{array}$ & $\begin{array}{l}168 \\
(50.6)\end{array}$ & $\begin{array}{l}168 \\
(37.8)\end{array}$ & \\
\hline
\end{tabular}




\begin{tabular}{|c|c|c|c|c|c|c|c|c|}
\hline Women & $\begin{array}{l}9736 \\
(55.1)\end{array}$ & $\begin{array}{l}7818 \\
(55.2)\end{array}$ & $\begin{array}{l}953 \\
(54.2)\end{array}$ & $\begin{array}{l}190 \\
(45.0)\end{array}$ & $\begin{array}{l}334 \\
(59.6)\end{array}$ & $\begin{array}{l}164 \\
(49.4)\end{array}$ & $\begin{array}{l}277 \\
(62.2)\end{array}$ & \\
\hline $\begin{array}{l}\text { Mean } \\
\text { BMI } \\
(\mathrm{kg} / \mathrm{m} \wedge 2) \\
(\mathrm{SD})\end{array}$ & $26.2(3.8)$ & $26.1(3.7)$ & $26.8(4.1)$ & $27.0(4.0)$ & $26.6(4.1)$ & $27.0(3.9)$ & $27.2(4.1)$ & $<0.001$ \\
\hline $\begin{array}{l}\text { Smoking } \\
\text { status } \\
(\%)\end{array}$ & & & & & & & & $<0.001$ \\
\hline Current & $\begin{array}{l}1959 \\
(11.1)\end{array}$ & $\begin{array}{l}1590 \\
(11.2)\end{array}$ & $\begin{array}{l}168 \\
(9.6)\end{array}$ & $\begin{array}{l}44 \\
(10.4)\end{array}$ & $\begin{array}{l}65 \\
(11.6)\end{array}$ & $23(6.9)$ & $\begin{array}{l}69 \\
(15.5)\end{array}$ & \\
\hline Former & $\begin{array}{l}7368 \\
(41.7)\end{array}$ & $\begin{array}{l}5704 \\
(40.3)\end{array}$ & $\begin{array}{l}826 \\
(47.0)\end{array}$ & $\begin{array}{l}218 \\
(51.7)\end{array}$ & $\begin{array}{l}253 \\
(45.2)\end{array}$ & $\begin{array}{l}166 \\
(50.0)\end{array}$ & $\begin{array}{l}201 \\
(45.2)\end{array}$ & \\
\hline Never & $\begin{array}{l}8351 \\
(47.2)\end{array}$ & $\begin{array}{l}6867 \\
(48.5)\end{array}$ & $\begin{array}{l}764 \\
(43.5)\end{array}$ & $\begin{array}{l}160 \\
(37.9)\end{array}$ & $\begin{array}{l}242 \\
(43.2)\end{array}$ & $\begin{array}{l}143 \\
(43.1)\end{array}$ & $\begin{array}{l}175 \\
(39.3)\end{array}$ & \\
\hline $\begin{array}{l}\text { Median } \\
\text { alcohol } \\
\text { consump- } \\
\text { tion } \\
\text { (units/week) } \\
\text { (IQR) }\end{array}$ & $\begin{array}{l}3.5 \\
(1.0-10.0)\end{array}$ & $\begin{array}{l}4.0 \\
(1.0-10.0)\end{array}$ & $\begin{array}{l}2.5(1.0- \\
9.0)\end{array}$ & $\begin{array}{l}2.5(1.0- \\
9.0)\end{array}$ & $\begin{array}{l}2.5(0.5- \\
8.5)\end{array}$ & $\begin{array}{l}2.5 \\
(1.0-9.5)\end{array}$ & $\begin{array}{l}2.0 \\
(0.5-6.8)\end{array}$ & $<0.001$ \\
\hline $\begin{array}{l}\text { Physical } \\
\text { activ- } \\
\text { ity } \\
(\%)\end{array}$ & & & & & & & & $<0.001$ \\
\hline Inactive & $\begin{array}{l}5216 \\
(29.5)\end{array}$ & $\begin{array}{l}3791 \\
(26.8)\end{array}$ & $\begin{array}{l}684 \\
(38.9)\end{array}$ & $\begin{array}{l}196 \\
(46.4)\end{array}$ & $\begin{array}{l}207 \\
(37.0)\end{array}$ & $\begin{array}{l}149 \\
(44.9)\end{array}$ & $\begin{array}{l}189 \\
(42.5)\end{array}$ & \\
\hline $\begin{array}{l}\text { Moderately } \\
\text { inac- } \\
\text { tive }\end{array}$ & $\begin{array}{l}5096 \\
(28.8)\end{array}$ & $\begin{array}{l}4111 \\
(29.0)\end{array}$ & $\begin{array}{l}489 \\
(27.8)\end{array}$ & $\begin{array}{l}108 \\
(25.6)\end{array}$ & $\begin{array}{l}172 \\
(30.7)\end{array}$ & $\begin{array}{l}89 \\
(26.8)\end{array}$ & $\begin{array}{l}127 \\
(28.5)\end{array}$ & \\
\hline $\begin{array}{l}\text { Moderately } \\
\text { active }\end{array}$ & $\begin{array}{l}4053 \\
(22.9)\end{array}$ & $\begin{array}{l}3410 \\
(24.1)\end{array}$ & $\begin{array}{l}344 \\
(19.6)\end{array}$ & $\begin{array}{l}61 \\
(14.5)\end{array}$ & $\begin{array}{l}108 \\
(19.3)\end{array}$ & $\begin{array}{l}42 \\
(12.7)\end{array}$ & $\begin{array}{l}88 \\
(19.8)\end{array}$ & \\
\hline Active & $\begin{array}{l}3313 \\
(18.7)\end{array}$ & $\begin{array}{l}2849 \\
(20.1)\end{array}$ & $\begin{array}{l}241 \\
(13.7)\end{array}$ & $\begin{array}{l}57 \\
(13.5)\end{array}$ & $\begin{array}{l}73 \\
(13.0)\end{array}$ & $\begin{array}{l}52 \\
(15.7)\end{array}$ & $41(9.2)$ & \\
\hline $\begin{array}{l}\text { Mean } \\
\text { total } \\
\text { choles- } \\
\text { terol } \\
(\mathrm{mmol} / \mathrm{l}) \\
(\mathrm{SD})\end{array}$ & $6.2(1.2)$ & $6.1(1.1)$ & $6.3(1.2)$ & $6.3(1.3)$ & $6.3(1.2)$ & $6.4(1.3)$ & $6.4(1.3)$ & $<0.001$ \\
\hline $\begin{array}{l}\text { Mean } \\
\text { total } \\
\text { fruits and } \\
\text { vegetables } \\
\text { consumed } \\
\text { (g/day) } \\
\text { (SD) }\end{array}$ & $\begin{array}{l}511.2 \\
(248.0)\end{array}$ & $\begin{array}{l}509.5 \\
(246.1)\end{array}$ & $\begin{array}{l}521.3 \\
(262.8)\end{array}$ & $\begin{array}{l}503.0 \\
(250.0)\end{array}$ & $\begin{array}{l}518.4 \\
(247.1)\end{array}$ & $\begin{array}{l}512.4 \\
(221.5)\end{array}$ & $\begin{array}{l}522.5 \\
(264.4)\end{array}$ & 0.17 \\
\hline $\begin{array}{l}\text { NSAID } \\
(\%)\end{array}$ & $\begin{array}{l}2592 \\
(14.7)\end{array}$ & $\begin{array}{l}1700 \\
(12.0)\end{array}$ & $\begin{array}{l}400 \\
(22.8)\end{array}$ & $\begin{array}{l}129 \\
(30.6)\end{array}$ & $\begin{array}{l}153 \\
(27.3)\end{array}$ & $\begin{array}{l}91 \\
(27.4)\end{array}$ & $\begin{array}{l}119 \\
(26.7)\end{array}$ & $<0.001$ \\
\hline
\end{tabular}




\begin{tabular}{|c|c|c|c|c|c|c|c|c|}
\hline $\begin{array}{l}\text { Lipid } \\
\text { lower- } \\
\text { ing } \\
\text { drugs } \\
\text { (\%) } \\
\text { Self- } \\
\text { reported } \\
\text { co- } \\
\text { morbidities } \\
(\%)\end{array}$ & $\begin{array}{l}256 \\
(1.4)\end{array}$ & $\begin{array}{l}135 \\
(1.0)\end{array}$ & $49(2.8)$ & $18(4.3)$ & $17(3.0)$ & $18(5.4)$ & $19(4.3)$ & $<0.001$ \\
\hline Diabetes & $384(2.2)$ & $230(1.6)$ & $63(3.6)$ & $28(6.6)$ & $23(4.1)$ & $18(5.4)$ & $22(4.9)$ & $<0.001$ \\
\hline Stroke & $255(1.4)$ & $125(0.9)$ & $56(3.2)$ & $30(7.1)$ & $13(2.3)$ & $12(3.6)$ & $19(4.3)$ & $<0.001$ \\
\hline Cancer & $923(5.2)$ & $686(4.8)$ & $107(6.1)$ & $29(6.9)$ & $47(8.4)$ & $24(7.2)$ & $30(6.7)$ & $<0.001$ \\
\hline $\begin{array}{l}\text { Heart } \\
\text { attack }\end{array}$ & $583(3.3)$ & 225 (1.6) & $131(7.5)$ & $71(16.8)$ & $65(11.6)$ & $41(12.3)$ & $50(11.2)$ & $<0.001$ \\
\hline $\begin{array}{l}\text { Median } \\
\text { CRP } \\
(\mathrm{mg} / \mathrm{l}) \\
\text { (IQR) }\end{array}$ & $\begin{array}{l}1.5 \\
(0.7-3.3)\end{array}$ & $\begin{array}{l}1.4 \\
(0.7-3.0)\end{array}$ & $\begin{array}{l}2.1 \\
(1.0-4.4)\end{array}$ & $\begin{array}{l}2.4 \\
(1.2-4.7)\end{array}$ & $\begin{array}{l}2.0 \\
(1.0-4.6)\end{array}$ & $\begin{array}{l}2.3 \\
(1.2-4.7)\end{array}$ & $\begin{array}{l}2.5 \\
(1.2-5.4)\end{array}$ & $<0.001$ \\
\hline
\end{tabular}

Note: Values presented are mean (SD) for normally distributed, continuous data, median (IQR) for nonnormally distributed, continuous data and number (\%) for categorical data. Total ACB was calculated with the formula of ((number of class 1 anticholinergics) + (number of class 2 anticholinergics $\times 2)+$ (number of class 3 anticholinergics $\times 3)$ ). Abbreviations: ACB, anticholinergic cognitive burden; BMI, body mass index; NSAID, non-steroidal anti-inflammatory drugs; CRP, C-reactive protein.

Table 3 Characteristics from $2^{\text {nd }}$ health-check for 5101 men and women in the EPIC-Norfolk cohort according to the total anticholinergic burden score groups.

\begin{tabular}{|c|c|c|c|c|c|c|c|c|}
\hline & All & $\begin{array}{l}\text { ACB } \\
\text { score } 0 \\
\text { group }\end{array}$ & $\begin{array}{l}\text { ACB } \\
\text { score } 1 \\
\text { group }\end{array}$ & $\begin{array}{l}\text { ACB } \\
\text { score 2 } \\
\text { group }\end{array}$ & $\begin{array}{l}\text { ACB } \\
\text { score } 3 \\
\text { group }\end{array}$ & $\begin{array}{l}\text { ACB } \\
\text { score } 4 \\
\text { group }\end{array}$ & $\begin{array}{l}\text { ACB } \\
\text { score } \\
{[?] 5} \\
\text { group }\end{array}$ & $p$ valu \\
\hline & $\begin{array}{l}\mathrm{N}=5101 \\
63189)\end{array}$ & $\begin{array}{l}N=3969 \\
62\end{array}$ & $\begin{array}{l}\mathrm{N}=608 \\
658(8,5)\end{array}$ & $\begin{array}{l}\mathrm{N}=133 \\
686(85)\end{array}$ & $\begin{array}{l}\mathrm{N}=157 \\
656(83)\end{array}$ & $\begin{array}{l}\mathrm{N}=79 \\
687(83)\end{array}$ & $\mathrm{N}=155$ & \\
\hline $\begin{array}{l}\text { Mean } \\
\text { age } \\
\text { (years) } \\
\text { (SD) }\end{array}$ & & & & & & & & $<0.001$ \\
\hline $\begin{array}{l}\text { Sex } \\
(\%)\end{array}$ & & & & & & & & 0.135 \\
\hline Men & $1963(38.5)$ & $1502(37.8)$ & $247(40.6)$ & $61(45.9)$ & $57(36.3)$ & $38(48.1)$ & $58(37.4)$ & \\
\hline Women & $3138(61.5)$ & $2467(62.2)$ & $361(59.4)$ & $72(54.1)$ & $100(63.7)$ & $41(51.9)$ & $97(62.6)$ & \\
\hline $\begin{array}{l}\text { Mean } \\
\text { BMI } \\
\left(\mathrm{kg} / \mathrm{m}^{\wedge} 2\right) \\
(\mathrm{SD})\end{array}$ & $26.6(3.8)$ & $26.4(3.8)$ & $27.2(4.1)$ & $27.5(4.3)$ & $27.1(4.0)$ & $27.4(4.2)$ & $27.8(3.8)$ & $<0.001$ \\
\hline $\begin{array}{l}\text { Smoking } \\
\text { status } \\
(\%)\end{array}$ & & & & & & & & 0.002 \\
\hline Current & $351(6.9)$ & $276(7.0)$ & $36(5.9)$ & $6(4.5)$ & $12(7.6)$ & $2(2.5)$ & $19(12.3)$ & \\
\hline Former & $2165(42.4)$ & 1633(41.1) & $281(46.2)$ & $58(43.6)$ & $81(51.6)$ & $40(50.6)$ & $72(46.5)$ & \\
\hline
\end{tabular}




\begin{tabular}{|c|c|c|c|c|c|c|c|c|}
\hline Never & $2585(50.7)$ & $2060(51.9)$ & $291(47.9)$ & $69(51.9)$ & $64(40.8)$ & $37(46.8)$ & $64(41.3)$ & \\
\hline $\begin{array}{l}\text { Median } \\
\text { alcohol } \\
\text { consump- } \\
\text { tion } \\
\text { (units/week } \\
\text { (IQR) }\end{array}$ & $3.0(1.0-9.0)$ & $3.0(1.0-9.0)$ & $2.5(1.0-9.0)$ & $3.0(0.5-8.5)$ & $3.0(1.0-8.5)$ & $3.0(1.0-9.0)$ & $2.0(0.5-9.0)$ & 0.046 \\
\hline $\begin{array}{l}\text { Physical } \\
\text { activ- } \\
\text { ity } \\
(\%)\end{array}$ & & & & & & & & $<0.001$ \\
\hline Inactive & $378(7.4)$ & $260(6.6)$ & $49(8.1)$ & $21(15.8)$ & $18(11.5)$ & $7(8.9)$ & $23(14.8)$ & \\
\hline $\begin{array}{l}\text { Moderately } \\
\text { inac- } \\
\text { tive }\end{array}$ & $1867(1238)$ & $1412(35.6)$ & $247(40.6)$ & $48(36.1)$ & $70(44.6)$ & $27(34.2)$ & $63(40.6)$ & \\
\hline $\begin{array}{l}\text { Moderately } \\
\text { active }\end{array}$ & $1238(24.3)$ & $979(24.7)$ & $142(23.4)$ & $29(21.8)$ & $35(22.3)$ & $20(25.3)$ & $33(21.3)$ & \\
\hline Active & $1618(31.7)$ & $1318(33.2)$ & $170(28.0)$ & $35(26.3)$ & $34(21.7)$ & $25(31.6)$ & $36(23.2)$ & \\
\hline $\begin{array}{l}\text { Mean } \\
\text { total } \\
\text { choles- } \\
\text { terol } \\
(\mathrm{mmol} / \mathrm{l}) \\
(\mathrm{SD})\end{array}$ & $6.1(1.2)$ & $6.1(1.2)$ & $6.1(1.1)$ & $6.0(1.3)$ & $6.1(1.2)$ & $6.1(1.0)$ & $6.4(1.3)$ & 0.008 \\
\hline $\begin{array}{l}\text { Mean } \\
\text { total } \\
\text { fruits and } \\
\text { vegetables } \\
\text { consumed } \\
\text { (g/day) } \\
\text { (SD) }\end{array}$ & $538.6(254.4)$ & $540.0(257.5)$ & $533.6(235.4)$ & $501.5(205.2)$ & $534.9(270.0)$ & $592.7(248.2)$ & $531.9(270.6)$ & 0.895 \\
\hline $\begin{array}{l}\text { NSAID } \\
(\%)\end{array}$ & $1100(21.6)$ & $690(17.4)$ & $199(32.7)$ & $61(45.9)$ & $60(38.2)$ & $32(40.5)$ & $58(37.4)$ & $<0.001$ \\
\hline $\begin{array}{l}\text { Lipid } \\
\text { lower- } \\
\text { ing } \\
\text { drugs } \\
(\%) \\
\text { Self- } \\
\text { reported } \\
\text { co- } \\
\text { morbidities }\end{array}$ & $275(5.4)$ & $141(3.6)$ & $66(10.9)$ & $23(17.3)$ & $20(12.7)$ & $10(12.7)$ & $15(9.7)$ & $<0.001$ \\
\hline Diabetes & $161(3.2)$ & $102(2.6)$ & $22(3.6)$ & $10(7.5)$ & $10(6.4)$ & $10(12.7)$ & $7(4.5)$ & $<0.001$ \\
\hline Stroke & $135(2.6)$ & $57(1.4)$ & $31(5.1)$ & $15(11.3)$ & $16(10.2)$ & $5(6.3)$ & $11(7.1)$ & $<0.001$ \\
\hline Cancer & $371(7.3)$ & $276(7.0)$ & $48(7.9)$ & $14(10.5)$ & $12(7.6)$ & $7(8.9)$ & $14(9.0)$ & 0.539 \\
\hline $\begin{array}{l}\text { Heart } \\
\text { attack }\end{array}$ & $157(3.1)$ & $46(1.2)$ & $52(8.6)$ & $19(14.3)$ & $11(7.0)$ & 11(13.9) & $18(11.6)$ & $<0.001$ \\
\hline
\end{tabular}




\begin{tabular}{|c|c|c|c|c|c|c|c|c|}
\hline 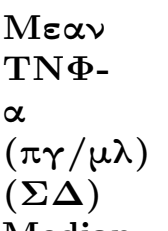 & $2.0(0.8)$ & $2.0(0.8)$ & $2.1(0.9)$ & $2.3(1.0)$ & $2.1(0.7)$ & $2.1(0.7)$ & $2.3(1.1)$ & $<0.001$ \\
\hline $\begin{array}{l}\text { Median } \\
\text { IL-6 } \\
(\mathrm{pg} / \mathrm{ml}) \\
(\mathrm{IQR})\end{array}$ & $\begin{array}{l}0.6(0.5- \\
0.9)\end{array}$ & $\begin{array}{l}0.6(0.5- \\
0.9)\end{array}$ & $\begin{array}{l}0.7(0.5- \\
1.0)\end{array}$ & $\begin{array}{l}0.8(0.5- \\
1.1)\end{array}$ & $\begin{array}{l}0.7(0.5- \\
1.0)\end{array}$ & $\begin{array}{l}0.8(0.6- \\
1.1)\end{array}$ & $\begin{array}{l}0.8(0.56- \\
1.2)\end{array}$ & $<0.001$ \\
\hline
\end{tabular}

Note: Values presented are mean (SD) for normally distributed, continuous data, median (IQR) for nonnormally distributed, continuous data and number (\%) for categorical data. Total ACB was calculated with the formula of ((number of class 1 anticholinergics) + (number of class 2 anticholinergics $\times 2)+$ (number of class 3 anticholinergics $\times 3)$ ). Abbreviations: ACB, anticholinergic cognitive burden; BMI, body mass index; NSAID, non-steroidal anti-inflammatory drugs; TNF- $\alpha$, tumour necrosis factor alpha; IL-6, interleukin 6.

Table 4 Cross sectional relationship between inflammatory markers and ACB score.

\begin{tabular}{|c|c|c|c|c|c|c|}
\hline \multicolumn{2}{|c|}{$\begin{array}{l}\text { INFLAMMATORMODEL } \\
\text { MARKER }\end{array}$} & \multirow{3}{*}{$\begin{array}{l}\beta \text { VALUE for } \\
1 \text { point } \\
\text { increase in } \\
\text { inflammatory } \\
\text { marker } \\
0.074\end{array}$} & \multirow{3}{*}{$\begin{array}{l}\beta \text { VALUE for } \\
\text { 1-SD increase } \\
\text { in } \\
\text { inflammatory } \\
\text { marker } \\
0.074\end{array}$} & \multirow{3}{*}{$\begin{array}{l}95 \% \text { CI } \\
\text { INTERVAL } \\
0.063,0.086\end{array}$} & \multirow{3}{*}{$\begin{array}{l}\text { Standard } \\
\text { Error (SE) } \\
0.006\end{array}$} & \multirow[t]{2}{*}{$p$ VALUE } \\
\hline MARKER & & & & & & \\
\hline Fibrinogen & $\mathrm{A}$ & & & & & $<0.001$ \\
\hline & B & 0.046 & 0.046 & $0.035,0.058$ & 0.006 & $<0.001$ \\
\hline & $\mathrm{C}$ & 0.037 & 0.037 & $0.025,0.049$ & 0.006 & $<0.001$ \\
\hline & D & 0.035 & 0.035 & $0.023,0.047$ & 0.006 & $<0.001$ \\
\hline \multirow{4}{*}{$\begin{array}{l}\text { CRP } \\
(\mathrm{mg} / \mathrm{l})(1 \mathrm{HC})\end{array}$} & $\mathrm{A}$ & 0.465 & 0.465 & $0.381,0.549$ & 0.043 & $<0.001$ \\
\hline & B & 0.372 & 0.372 & $0.287,0.456$ & 0.043 & $<0.001$ \\
\hline & $\mathrm{C}$ & 0.304 & 0.304 & $0.220,0.389$ & 0.043 & $<0.001$ \\
\hline & D & 0.284 & 0.284 & $0.198,0.369$ & 0.044 & $<0.001$ \\
\hline \multirow{4}{*}{$\begin{array}{l}\text { IL-6 } \\
(\mathrm{pg} / \mathrm{ml})(2 \mathrm{HC})\end{array}$} & $\mathrm{A}$ & 0.129 & 0.052 & $0.068,0.190$ & 0.031 & $<0.001$ \\
\hline & B & 0.113 & 0.045 & $0.051,0.174$ & 0.031 & $<0.001$ \\
\hline & $\mathrm{C}$ & 0.107 & 0.043 & $0.045,0.169$ & 0.032 & 0.001 \\
\hline & $\mathrm{D}$ & 0.112 & 0.045 & $0.048,0.175$ & 0.033 & 0.001 \\
\hline \multirow{4}{*}{$\begin{array}{l}\text { TNF- } \alpha \\
(\mathrm{pg} / \mathrm{ml})(2 \mathrm{HC})\end{array}$} & $\mathrm{A}$ & 0.065 & 0.081 & $0.045,0.084$ & 0.010 & $<0.001$ \\
\hline & B & 0.042 & 0.053 & $0.023,0.061$ & 0.010 & $<0.001$ \\
\hline & $\mathrm{C}$ & 0.037 & 0.046 & $0.018,0.056$ & 0.010 & $<0.001$ \\
\hline & $\mathrm{D}$ & 0.031 & 0.039 & $0.011,0.050$ & 0.010 & 0.002 \\
\hline
\end{tabular}

Note: This is the linear regression analysis of inflammatory markers and ACB score. Inflammatory markers fibrinogen and CRP were collected in the first health check and TNF- $\alpha$ and IL- 6 were collected in the second health check. To demonstrate a cross-sectional relationship, the exposure for fibrinogen and CRP was baseline data from the first health check whilst for IL- 6 and TNF- $\alpha$, the exposure was participants' data from the second health check. The following models adjust for the ACB groups and inflammatory marker: $\mathrm{A}=$ univariate model, $\mathrm{B}=$ age and sex $\mathrm{C}=$ age, sex and lifestyle factors (BMI, alcohol consumption 
smoking status, total fruits and vegetables consumed and physical activity), $\mathrm{D}=$ age, sex, lifestyle factors, total cholesterol, medications (lipid lowering drugs, NSAIDs) and self-reported co-morbidities (stroke, cancer, heart attack and diabetes). Abbreviations: $1 \mathrm{HC}$, first health check; $2 \mathrm{HC}$, second health check; SD, standard deviation; CI, confidence interval.

Table 5 Longitudinal relationship of inflammatory markers IL-6 and TNF- $\alpha$ for 5,101 participants.

\begin{tabular}{|c|c|c|c|c|c|c|}
\hline INFLAMMA] & RMODEL & $\beta$ VALUE for & $\beta$ VALUE for & $95 \%$ CI & Standard & $p$ VALUE \\
\hline MARKER & & $\begin{array}{l}1 \text { point } \\
\text { increase in } \\
\text { inflammatory } \\
\text { marker }\end{array}$ & $\begin{array}{l}\text { 1-SD increase } \\
\text { in } \\
\text { inflammatory } \\
\text { marker }\end{array}$ & INTERVAL & Error (SE) & \\
\hline IL-6 $(\mathrm{pg} / \mathrm{ml})$ & A & 0.098 & 0.039 & $0.030,0.166$ & 0.035 & 0.005 \\
\hline & B & 0.078 & 0.031 & $0.009,0.146$ & 0.035 & 0.026 \\
\hline & $\mathrm{C}$ & 0.079 & 0.032 & $0.013,0.145$ & 0.034 & 0.020 \\
\hline & $\mathrm{D}$ & 0.076 & 0.030 & $0.008,0.144$ & 0.035 & 0.029 \\
\hline TNF- $\alpha$ & $\mathrm{A}$ & 0.064 & 0.080 & $0.043,0.085$ & 0.011 & $<0.001$ \\
\hline & B & 0.040 & 0.050 & $0.019,0.061$ & 0.011 & $<0.001$ \\
\hline & $\mathrm{C}$ & 0.036 & 0.045 & $0.015,0.058$ & 0.011 & 0.001 \\
\hline & $\mathrm{D}$ & 0.028 & 0.035 & $0.006,0.050$ & 0.011 & 0.013 \\
\hline
\end{tabular}

Note: This is the linear regression analysis for inflammatory markers and ACB score. The exposure was baseline data from the first health check to demonstrate a longitudinal relationship because TNF- $\alpha$ and IL-6 were collected in the second health check.

The following models adjust for the $\mathrm{ACB}$ groups and inflammatory marker: $\mathrm{A}=$ univariate model, $\mathrm{B}=$ age and sex, $\mathrm{C}=$ age, sex and lifestyle factors (BMI, alcohol consumption, smoking status, total fruits and vegetables consumed and physical activity), $\mathrm{D}=$ age, sex, lifestyle factors, total cholesterol, medications (lipid lowering drugs, NSAIDs), co-morbidities (stroke, cancer, heart attack and diabetes) . Abbreviations: 1HC, first health check; 2HC, second health check; SD, standard deviation; CI, confidence interval.

\section{FIGURES}

Fig.1 The EPIC-Norfolk cohort timeline and the analyses undertaken.

Fig.2 The participant population flowchart. 


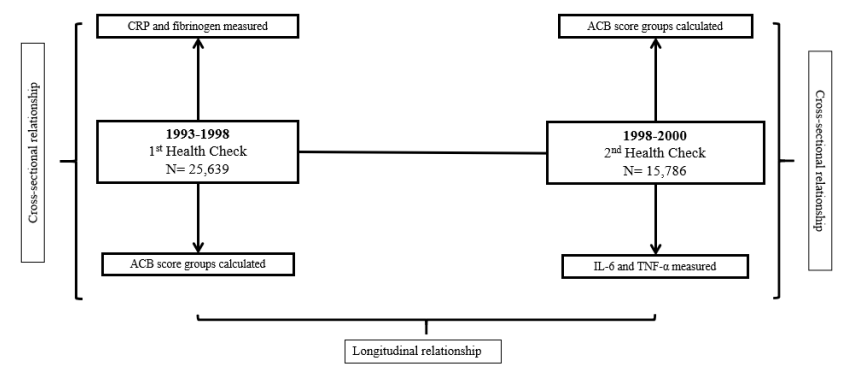




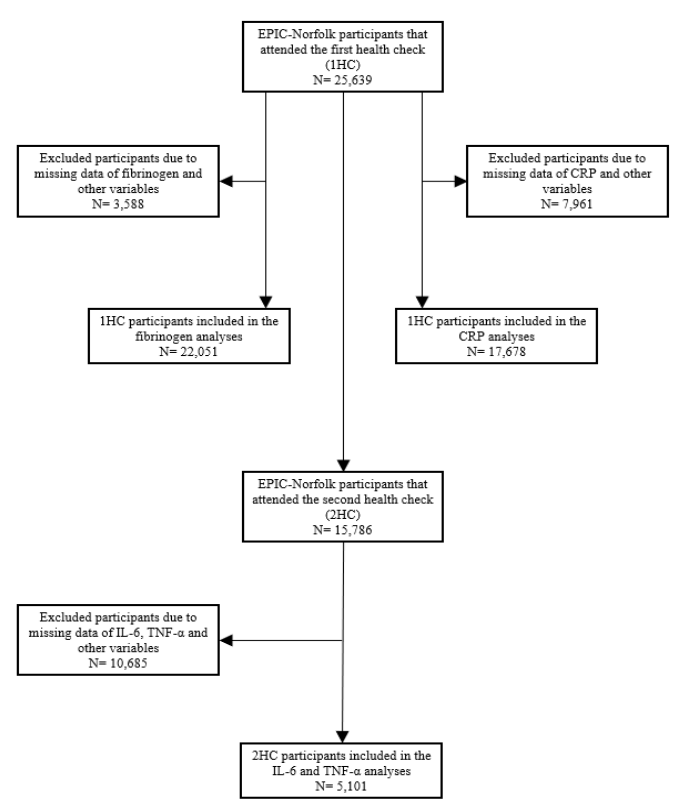

